\title{
Productivity and quality of Mombasa grass under fertilization with pig deep-litter and NPK
}

\author{
Marina da C. Guerrero ${ }^{1}$, Tiago R. de Sousa ${ }^{1}$, Saulo A. de Oliveira ${ }^{2}$, Rômulo R. Caldeira ${ }^{2}$ \& Adilson Pelá $^{1}$ \\ ${ }^{1}$ Universidade Estadual de Goiás/Programa de Pós-Graduação em Produção Vegetal, Ipameri, GO, Brasil. E-mail: marinaagro@hotmail.com - ORCID: \\ 0000-0001-9242-211X; tiago.r.agronomia@gmail.com - ORCID: 0000-0002-9688-9929; adilson.pela@ueg.br (Corresponding author) - ORCID: 0000- \\ $0002-4742-2468$ \\ ${ }_{2}^{2}$ Universidade Estadual de Goiás/Departamento de Agronomia e Engenharia Florestal, Ipameri, GO, Brasil. E-mail: profsauloueg@outlook.com - ORCID: \\ 0000-0002-0707-549X; romulo.rocha.caldeira@gmail.com - ORCID: 0000-0003-0757-1300
}

\begin{abstract}
The use of pig deep-litter (PDL) in pasture fertilization can be an important alternative from an environmental and economic point of view. This study was conducted to evaluate the fertilization with PDL exclusively or in association with mineral fertilizers on the quality and productivity of Panicum maximum cv. Mombasa. The experiment was carried out in Ipameri, GO, Brazil. The design was a randomized block design in a $2 \times 5$ factorial scheme with four repetitions, in plots of $24 \mathrm{~m}^{2}$. The doses of PDL $\left(0 ; 5 ; 10 ; 15\right.$ and $\left.20 \mathrm{Mg} \mathrm{ha}^{-1}\right)$ were tested, with or without fertilization with NPK ( $50 \mathrm{~kg} \mathrm{ha}^{-1}$ of $\mathrm{P}_{2} \mathrm{O}_{5}, 10 \mathrm{~kg} \mathrm{ha}^{-1}$ of $\mathrm{K}_{2} \mathrm{O}$ and $10 \mathrm{~kg} \mathrm{ha}^{-1}$ of N). The organic fertilizer was applied broadcast at the planting of the pasture, and the mineral fertilizers were split and applied at planting and as topdressing. Dry mass, crude protein, acid detergent fiber and neutral detergent fiber were evaluated. PDL doses associated with mineral fertilization led to linear increases from 52 to $282 \%$ in the analyzed variables and better bromatological composition. PDL application is beneficial to the production of pastures, and increasing applications up to the PDL dose of $20 \mathrm{Mg} \mathrm{ha}^{-1}$ associated with mineral fertilization promoted better quantitative and qualitative results. With exclusive fertilization with PDL, the gains in quality and productivity were more modest.
\end{abstract}

Key words: Panicum maximum, crude protein, neutral detergent fiber, acid detergent fiber

\section{Produtividade e qualidade do capim Mombaça sob adubação com cama sobreposta de suínos e NPK}

\begin{abstract}
RESUMO: O uso de cama sobreposta de suínos (CSS) na adubação de pastagens pode ser uma importante alternativa do ponto de vista ambiental e econômico. Com o objetivo de avaliar a adubação com CSS de forma exclusiva ou associada a fertilizantes minerais, na qualidade e produtividade de Panicum maximum cv. Mombaça, foi conduzido um experimento em condições de campo, em Ipameri, GO. O delineamento foi em blocos ao acaso em esquema fatorial 2 x 5 com quatro repetições, em parcelas de $24 \mathrm{~m}^{2}$. Foram testadas as doses de CSS (0; 5; 10; 15 e $\left.20 \mathrm{Mg} \mathrm{ha}^{-1}\right)$, com ou sem adubação com NPK (50 kg ha-1 de $\mathrm{P}_{2} \mathrm{O}_{5}, 10 \mathrm{~kg} \mathrm{ha}^{-1}$ de $\mathrm{K}_{2} \mathrm{O}$ e $10 \mathrm{~kg} \mathrm{ha}^{-1}$ de N). O adubo orgânico foi aplicado a lanço na implantação da pastagem, e os fertilizantes minerais parcelados no plantio e em cobertura. Foram avaliadas a massa seca, proteína bruta, fibra em detergente ácido e fibra em detergente neutro. As doses de CSS associadas à adubação mineral apresentaram incrementos lineares de 52 a 282\% nas variáveis avaliadas, e melhor composição bromatológica. A aplicação de CSS é benéfica à produção de pastagens e as aplicações crescentes até à dose de $20 \mathrm{Mg} \mathrm{ha}^{-1}$ de CSS associadas à adubação mineral apresentaram melhores resultados quantitativos e qualitativos. Com a adubação exclusiva com CSS os ganhos de qualidade e produtividade do capim Mombaça são menores.
\end{abstract}

Palavras-chave: Panicum maximum, proteína bruta, fibra em detergente neutro, fibra em detergente ácido 


\section{INTRODUCTION}

In Brazil, pasture is the main food source for most of the cattle herd, mainly because it provides lower production cost. The system is characterized by extractivism, where the adoption of technologies and intensive use in capital is restricted to a small set of producers (Barcellos et al., 2008). According to Carvalho et al. (2017), it is estimated that $80 \%$ of the 50-60 million hectares of pasture cultivated in the Central region of Brazil are in some state of degradation.

In the Cerrado, the introduction of selected forage plants enabled significant gains in the animal stocking rate compared to native species (Martha Júnior \& Vilela, 2002). Mombasa grass (Panicum maximum cv. Mombasa) is considered one of the most productive tropical forage species available to livestock farmers. However, in situations of low fertility, production is reduced, as the forage is demanding in terms of soil fertility (Freitas et al., 2007).

Pasture fertilization is often considered to be unfeasible for producers. Thus, the use of organic waste such as those from pig farming can be a good alternative as a source of nutrients (Cardoso et al., 2015), besides reducing environmental impacts (Rizzoni et al., 2012).

The deep-litter pig production system is still recent in Brazil and has the advantages of greater comfort to animals, lower stress in the intensive production system and low costs of implementation and operation of the system, reducing the need for complementary structures, such as ponds for waste treatment (Homem et al., 2015). In this system, the animals are raised in facilities whose floor is formed by wood shavings, straw or rice husk, where the waste goes through the "in situ" composting process.

Organic fertilizers contain highly variable concentrations and rates of nutrient release in the soil, and for pig deep-litter (PDL) there are still no indices of availability (IA) of the main nutrients, such as nitrogen, phosphorus and potassium (Hentz et al., 2008). As the PDL system is recent, little is known about the quantities to be used in crops, exclusively or associated with NPK fertilization. The hypothesis of this study is that fertilization with PDL associated with mineral fertilizers has a synergistic effect on the quality and productivity of Mombasa grass.

This study aimed to evaluate the effect of PDL, exclusively or associated with mineral fertilizers, on the productive and qualitative characteristics of Panicum maximum cv. Mombasa.

\section{Material ANd Methods}

The experiment was carried out under field conditions in the experimental area of the Universidade Estadual de Goiás Campus of Ipameri, located on the GO 330 highway, km 241, Brazil ( $17^{\circ} 42^{\prime} 54^{\prime \prime}$ S, 48 $8^{\prime} 36^{\prime \prime} \mathrm{W}$ and altitude of $803 \mathrm{~m}$ ), in the period from December 2015 to May 2016, in the edaphoclimatic region of Southeastern Goiás, Brazil, in Oxisol. The experimental period comprised the planting and maintenance of the pasture of Panicum maximum cv. Mombasa.

The climate of the region, according to the Köppen's classification, is semi-humid tropical (Aw), with high temperatures, with annual averages from 20 to $24^{\circ} \mathrm{C}$, summer rains from 1300 to $1700 \mathrm{~mm}$ and dry winter. The climatic conditions observed along the experimental period are shown in Figure 1.

The experimental design used was in randomized blocks, in a $2 \times 5$ factorial scheme, with four replicates. The first factor corresponded to mineral fertilization with NPK (without and with). The second factor consisted of pig deep-litter (PDL) doses of $0,5,10,15$ and $20 \mathrm{Mg} \mathrm{ha}^{-1}$, with $48.36 \%$ moisture, distributed throughout the area and incorporated into the soil in the $0-5 \mathrm{~cm}$ layer 10 days before sowing the grass. Mineral fertilization with NPK was applied based on soil analysis and according to the recommendations of Cantarutti et al. (1999), for pasture of high technological level.

PDL was acquired at Grão Dourado farm, in the municipality of Ipameri, GO, Brazil, which has breeding, weaning and finishing phases of pigs. The bedding removed from the facilities is the result of the mixture of beddings of all rearing stages. The carbonaceous material used to make the bedding was rice straw. In its analysis, the following parameters were determined: dry mass $=51.64 \% ; \mathrm{N}=15.6 \mathrm{~g} \mathrm{~kg}^{-1} ; \mathrm{P}_{2} \mathrm{O}_{5}=43.0 \mathrm{~g} \mathrm{~kg}^{-1}$ and $\mathrm{K}_{2} \mathrm{O}=21.5 \mathrm{~g} \mathrm{~kg}^{-1}$.

Soil sampling was performed in the area before installing the experiment, in the layer from 0 to $20 \mathrm{~cm}$ for chemical characterization. The results obtained were: $\mathrm{pH}-4.6 ; \mathrm{P}$ (Mehlich 1) $-1.5 \mathrm{mg} \mathrm{dm}^{-3} ; \mathrm{K}-39.0 \mathrm{mg} \mathrm{dm}{ }^{-3} ; \mathrm{H}+\mathrm{Al}-1.5 \mathrm{cmol}_{\mathrm{c}} \mathrm{dm}^{-3}$; $\mathrm{Al}^{3+}-0.4 \mathrm{cmol}_{\mathrm{c}} \mathrm{dm}^{-3} ; \mathrm{Ca}-1.3 \mathrm{cmol}_{\mathrm{c}} \mathrm{dm}^{-3} ; \mathrm{Mg}-0.54 \mathrm{cmol}_{\mathrm{c}} \mathrm{dm}^{-3}$; OM - $18.0 \mathrm{~g} \mathrm{dm}^{-3}$; CEC - $3.42 \mathrm{cmol}_{\mathrm{c}} \mathrm{dm}^{-3}$, clay content $-250 \mathrm{~g} \mathrm{~kg}^{-1}$ and base saturation - $56.06 \%$.

Soil tillage for the experiment was performed by means of three harrowing operations. Basal fertilization consisted of $50 \mathrm{~kg} \mathrm{ha}^{-1}$ of $\mathrm{P}_{2} \mathrm{O}_{5}, 10 \mathrm{~kg} \mathrm{ha}^{-1}$ of $\mathrm{K}_{2} \mathrm{O}$ and $10 \mathrm{~kg} \mathrm{ha}^{-1}$ of N, using as source triple superphosphate, potassium chloride and urea, respectively, based on soil analysis and according to the recommendations of Cantarutti et al. (1999), considering pastures of high technological level. Liming was not performed because the base saturation of the soil was above the recommended level for the species.

Broadcast manual sowing was performed in $6 \times 4 \mathrm{~m}$ plots, with a total area of $24 \mathrm{~m}^{2}$ each, incorporating the seeds to the soil with a closed leveling harrow. The amount used was $20 \mathrm{~kg} \mathrm{ha}^{-1}$ of coated seeds of Panicum maximum cultivar Mombasa, which had $96.12 \%$ purity and cultural value of $80 \%$.

Topdressing fertilization was performed when the grass covered $60 \%$ of the soil, at 42 days after seedling emergence (DAE), using $50 \mathrm{~kg} \mathrm{ha}^{-1}$ of $\mathrm{N}$ and $50 \mathrm{~kg} \mathrm{ha}^{-1}$ of $\mathrm{K}_{2} \mathrm{O}$, using urea and

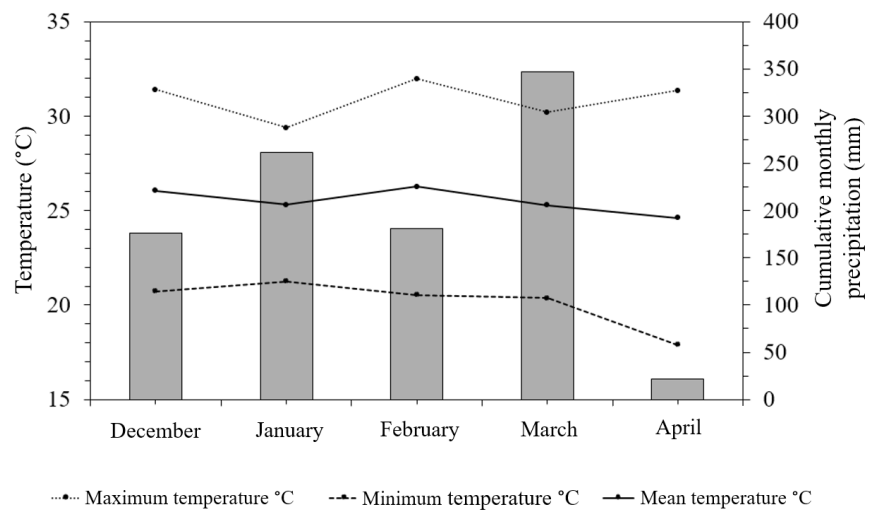

Source: INMET (2016)

Figure 1. Cumulative monthly precipitation and temperatures recorded from December 2015 to May 2016 
$\mathrm{KCl}$ as sources, respectively. Topdressing nitrogen fertilization was repeated after each cutting, in applications of $50 \mathrm{~kg} \mathrm{ha}^{-1}$ of $\mathrm{N}$, using urea as source of $\mathrm{N}$, at 64, 95 and 133 DAE. After the fourth cutting (173 DAE), no nitrogen fertilization was performed due to lack of rainfall. Grass height was considered for each cutting, which was performed when it reached $90 \mathrm{~cm}$.

The samples were collected using a $1 \mathrm{~m}^{2}$ frame randomly thrown in the plot, then the sample was cut respecting the height of the grass, leaving a residue of $45 \mathrm{~cm}$.

The analysis of dry mass production (DM) was determined based on the mass of the aerial part (stems + leaves) of the obtained sample. After weighing, the material was chopped and homogenized, and 100-g subsamples were dried in a forced air circulation oven at $65^{\circ} \mathrm{C}$ until reaching constant weight, thus determining the water content, correcting the fresh mass (FM).

Then, the dry subsamples were ground in a Wiley-type mill to perform the other analyses. For forage quality analysis, the contents of crude protein (CP), neutral detergent fiber (NDF) and acid detergent fiber (ADF) were considered according to procedures described by Rodrigues (2010). N was determined by the Kjeldahl method and was used for crude protein calculation, multiplying by factor 6.25 (Silva \& Queiroz, 2006).

The obtained data were subjected to analysis of variance by F test. Effects of NPK fertilization were compared by the Scott-Knott test at $\mathrm{p} \leq 0.05$ while PDL doses were evaluated by regression analysis. Statistical calculations were performed using the software program Sisvar 5.3 (Ferreira, 2011).

\section{Results AND Discussion}

The $\mathrm{F}$ test was significant at $\mathrm{p} \leq 0.01$ for the variables DM, CP, NDF, ADF and FTMS, for the effects of mineral fertilization, for PDL doses, as well as for the interaction between both, in all cuttings and in the total, except for the MF $x$ PDL interaction for NDF in the $1^{\text {st }}$ and $4^{\text {th }}$ cuts and ADF in the $1^{\text {st }}$ and $3^{\text {rd }}$ cuts, which had no significant effect. ADF in the $2^{\text {nd }}$ cutting was also not significantly affected by MF (Table 1 ). These results show that both MF and PDL fertilization interfere with Mombasa productivity and quality.

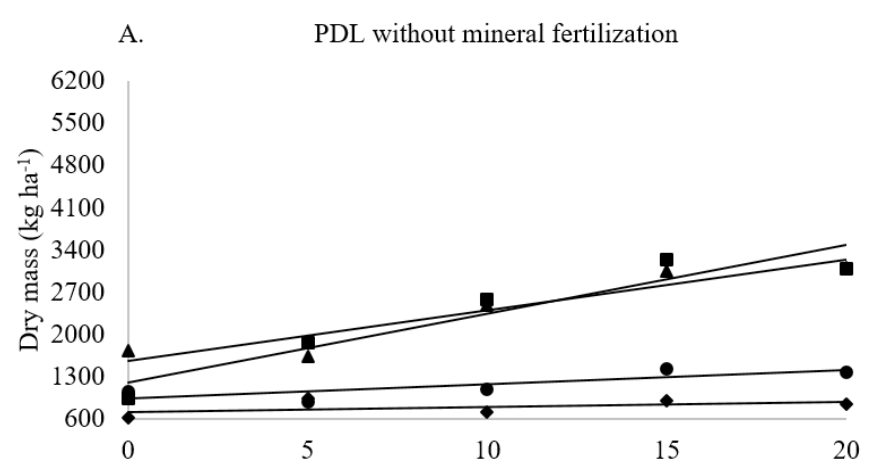

\footnotetext{
- $\quad 1^{\text {st }}$ cut $\mathrm{Y}=1115+135.74 * * \mathrm{x}\left(\mathrm{R}^{2}=0.97\right)$

- $\quad 2^{\text {nd }}$ cut $\mathrm{Y}=639+29.96 * * \mathrm{x}\left(\mathrm{R}^{2}=0.94\right)$

- $\quad 3^{\text {rd }}$ cut $\mathrm{Y}=939+16.38 * * x\left(\mathrm{R}^{2}=0.95\right)$

$\Delta \quad 4^{\text {th }}$ cut $\mathrm{Y}=1561+86.14^{* *} \mathrm{x}\left(\mathrm{R}^{2}=0.92\right)$
}

"Significant at $\mathrm{p} \leq 0.01$ by F test

Figure 2. Dry mass productivity of Mombasa grass as a function of pig deep-litter doses (PDL) without (A) and with (B) mineral fertilization
Table 1. Summary of the analysis of variance for dry mass (DM), crude protein (CP), neutral detergent fiber (NDF), acid detergent fiber (ADF) and total dry mass productivity (TDMP), for Panicum maximum cv. Mombasa

\begin{tabular}{|c|c|c|c|c|c|}
\hline \multirow{2}{*}{$\begin{array}{c}\text { Source } \\
\text { of variation }\end{array}$} & \multirow{2}{*}{ DF } & \multicolumn{4}{|c|}{ Mean squares } \\
\hline & & $\overline{D M}$ & CP & NDF & ADF \\
\hline & & \multicolumn{4}{|c|}{$1^{\text {st }}$ cutting } \\
\hline MF & 1 & $36903370.5062^{\star \star}$ & $27.1590^{\star \star}$ & $12.3432^{\star \star}$ & $39.2040^{\star \star}$ \\
\hline PDL doses & 4 & $10870925.1312^{\star *}$ & $11.5474^{* *}$ & $11.9680^{* *}$ & $9.0504^{* \star}$ \\
\hline MF x PDL & 4 & $808863.9437^{* *}$ & $0.4352^{* \star}$ & $0.3211^{\text {ns }}$ & $0.2412^{\mathrm{ns}}$ \\
\hline Residual & 27 & 21774.4414 & 0.0290 & 0.4016 & 0.4026 \\
\hline CV (\%) & - & 4.8 & 2.06 & 0.88 & 1.55 \\
\hline \multirow[t]{2}{*}{ LSD } & - & 95.74 & 0.11 & 0.41 & 0.41 \\
\hline & & \multicolumn{4}{|c|}{$2^{\text {nd }}$ cutting } \\
\hline MF & 1 & 845388.0520 ** & $24.1647^{\star *}$ & $41.6976^{\star \star}$ & $0.0656^{\mathrm{ns}}$ \\
\hline PDL doses & 4 & $311213.0375^{\star *}$ & $12.7976^{* *}$ & $11.0439 * *$ & $0.8962^{*}$ \\
\hline MF x PDL & 4 & $40660.8375^{\star \star}$ & $0.6656^{\star \star}$ & $85.0185^{\star \star}$ & $23.2522^{\star \star}$ \\
\hline Residual & 27 & 1562.1102 & 0.0119 & 0.4505 & 0.2639 \\
\hline CV (\%) & - & 3.13 & 1.32 & 0.95 & 1.21 \\
\hline \multirow[t]{2}{*}{ LSD } & - & 25.64 & 0.07 & 0.43 & 0.33 \\
\hline & & \multicolumn{4}{|c|}{$3^{\text {rd }}$ cutting } \\
\hline MF & 1 & $53107202.5000 * *$ & $16.9000^{* *}$ & $310.8062^{* *}$ & $72.5764^{* *}$ \\
\hline PDL doses & 4 & $1804420.9375^{\star \star}$ & $4.2504^{\star \star}$ & $71.7501 * \star$ & 37.3921 ** \\
\hline MF x PDL & 4 & $497157.1875^{\star \star}$ & $0.6132^{\star \star}$ & $8.5647^{\star \star}$ & $0.9428 \mathrm{~ns}$ \\
\hline Residual & 27 & 21346.6667 & 0.0064 & 9.1975 & 0.4657 \\
\hline CV (\%) & - & 6.37 & 1.03 & 0.85 & 1.92 \\
\hline \multirow[t]{2}{*}{ LSD } & - & 94.80 & 0.051 & 0.38 & 0.44 \\
\hline & & \multicolumn{4}{|c|}{$4^{\text {th }}$ cutting } \\
\hline MF & 1 & 7695675.6250 ** & $22.1563^{* *}$ & $40.6426^{\star \star}$ & $825.7357^{* *}$ \\
\hline PDL doses & 4 & 13502158.7500 ** & $24.6018 * *$ & $9.2228 * \star$ & $20.9077^{\star \star}$ \\
\hline MF $\times$ PDL & 4 & 553658.7500 ** & $0.5274^{\star \star}$ & $0.4470^{\text {ns }}$ & $1.6762^{\star \star}$ \\
\hline Residual & 27 & 850984.3750 & 0.6840 & 0.3934 & 0.3531 \\
\hline CV (\%) & - & 6.20 & 1.99 & 0.84 & 1.28 \\
\hline \multirow[t]{2}{*}{$\underline{\mathrm{LSD}}$} & - & 115.19 & 0.10 & 0.41 & 0.38 \\
\hline & & \multicolumn{4}{|c|}{ TDMP } \\
\hline MF & 1 & 126504705.6250 ** & - & - & - \\
\hline PDL doses & 4 & $42324295.9375^{\star *}$ & - & - & - \\
\hline MF $\times$ PDL & 4 & $1073822.8125^{\star}$ & - & - & - \\
\hline Residual & 27 & 279799.5138 & - & - & - \\
\hline CV (\%) & - & 4.51 & - & - & - \\
\hline LSD & - & 343.21 & - & - & - \\
\hline
\end{tabular}

The dry mass of Mombasa grass showed linear fits $(\mathrm{p} \leq 0.01)$ as a function of PDL doses, in all cuttings, in the absence or in the presence of mineral fertilization (Figure 2).

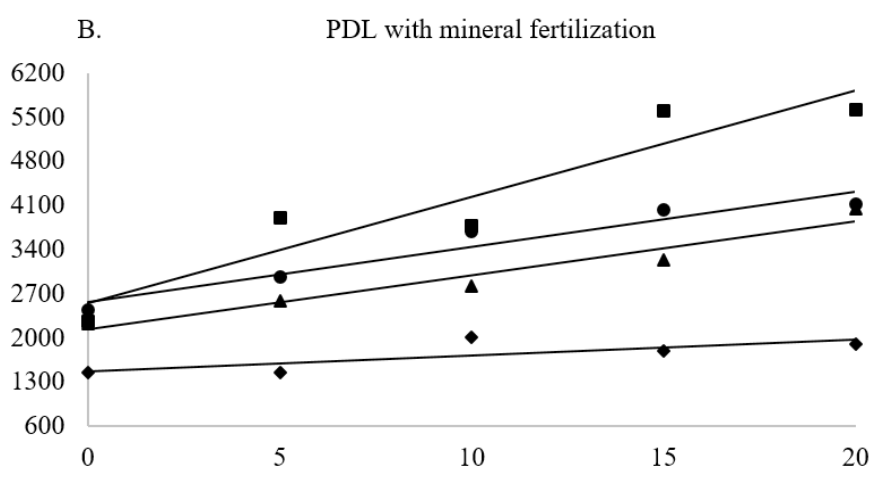

\footnotetext{
- $\quad 1^{\text {st }}$ cut $\mathrm{Y}=2525.6+172.5^{*} * \mathrm{x}\left(\mathrm{R}^{2}=0.92\right)$

- $\quad 2^{\text {nd }}$ cut $\mathrm{Y}=1401.8+32.0488 * * \mathrm{x}\left(\mathrm{R}^{2}=0.91\right)$

- $\quad 3^{\text {rd }}$ cut $\mathrm{Y}=2568.4+87.84 * * \mathrm{x}\left(\mathrm{R}^{2}=0.93\right)$

$\Delta \quad 4^{\text {th }}$ cut $\mathrm{Y}=2132.2+85.48 * * \mathrm{x}\left(\mathrm{R}^{2}=0.98\right)$
} 
In the first cut, it was found that the fertilization with PDL, when compared to the treatment that did not receive any fertilization, led to a $243.48 \%$ increase in dry mass productivity (DM), for the application of $20 \mathrm{Mg} \mathrm{ha}^{-1}$ of PDL (Figure 2A). Application of mineral fertilizer together with PDL enabled a $136.6 \%$ increase in DM compared to the treatment that received only mineral fertilization (Figure $2 \mathrm{~B}$ ). When comparing the productivity gains of organic fertilization with those of mineral fertilization, the second leads to a smaller increment, but its productivity is $2145.80 \mathrm{~kg} \mathrm{ha}^{-1}$ higher than that with PDL fertilization at dose of $20 \mathrm{Mg} \mathrm{ha}^{-1}$. Thus, it is possible to affirm that the highest dose of PDL associated with mineral fertilization leads to the highest DM productivity.

In the second cut, the increment found in organic fertilization at the dose of $20 \mathrm{Mg} \mathrm{ha}^{-1}$, compared to the treatment that did not receive any fertilization, was equal to $93.77 \%$, and for fertilization with PDL associated with mineral fertilization, the increase in comparison to the treatment that received only mineral fertilization was $45.73 \%$. Despite the difference between the increase gain, the treatment with associated fertilization led to $804.58 \mathrm{~kg} \mathrm{ha}^{-1}$ more in comparison to the PDL dose of $20 \mathrm{Mg} \mathrm{ha}^{-1}$. The DM productivity of the second cutting was lower than that of the others (Figure 2), which may be directly related to the lower volume of rainfall in this period.

In the third and fourth cuts, there were increments of 34.89 and $110.36 \%$, respectively, in organic fertilization with $20 \mathrm{Mg} \mathrm{ha}^{-1}$ compared to the treatment that did not receive any fertilization, and for fertilization associated with $20 \mathrm{Mg} \mathrm{ha}^{-1}$ of PDL and mineral fertilization the increments in comparison to the treatment that received only mineral fertilization were 68.40 and $80.18 \%$, respectively. The treatment with associated fertilization in the third cutting promoted $3058.60 \mathrm{~kg} \mathrm{ha}^{-1}$ more DM production than the dose of $20 \mathrm{Mg} \mathrm{ha}^{-1}$ of organic fertilization and, the fourth cutting, led to $558.00 \mathrm{~kg} \mathrm{ha}^{-1}$ more in comparison to the dose of $20 \mathrm{Mg} \mathrm{ha}^{-1}$ of organic fertilization.

According to Araújo et al. (2008), the highest values of DM production observed for treatments produced from animal residues can be explained because manures promoted better chemical conditions in the soil, providing nutrients for a more efficient absorption by the root system, and virtually the essential nutrients are in their mineralized form.

Barnabé et al. (2007), evaluating the fertigation of Brachiaria brizantha cv. Marandu with liquid swine manure, observed that the application of $150 \mathrm{~m}^{3} \mathrm{ha}^{-1}$ (highest dose) led to the highest productivity, as in the present study. Data found in the study conducted by Orrico Junior et al. (2012), using biofertilizer from cattle and pig manure for Piatã grass fertilization, also indicated better results with the highest doses of biofertilizer, up to the $\mathrm{N}$ dose of $300 \mathrm{~kg} \mathrm{ha}^{-1}$.

In an overall analysis comparing the fertilizations in the sum of the cuttings, it can be observed that the best results were obtained with the doses of pig deep-litter (PDL) plus mineral fertilization (MF) (Figure 3).

For treatments that received only PDL in the sum of the four cuttings, there was a quadratic behavior, reaching a maximum point with PDL dose of $19.72 \mathrm{Mg} \mathrm{ha}^{-1}$, producing 12.14 $\mathrm{Mg} \mathrm{ha}^{-1}$ of DM. The associated fertilization of PDL plus mineral fertilization with NPK led to a $80.55 \%$ increase compared to

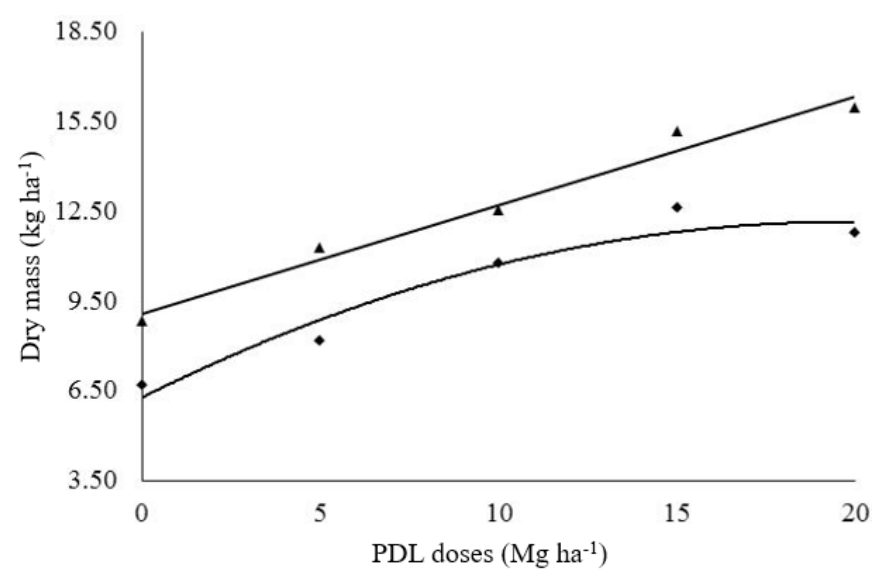

- PDL $\mathrm{Y}=6.2683+0.5957 * * \mathrm{x}-0.0151 * * \mathrm{x}^{2}\left(\mathrm{R}^{2}=0.94\right)$

\PDL MF $\mathrm{Y}=9.053+0.3642 * * \mathrm{x}\left(\mathrm{R}^{2}=0.97\right)$

** Significant at $\mathrm{p} \leq 0.01$ by $\mathrm{F}$ test

Figure 3. Total dry mass productivity of Mombasa grass as a function of the doses of pig deep-litter (PDL), with and without mineral fertilization (MF), referring to the average of the four cuttings

the control, producing $16.34 \mathrm{Mg} \mathrm{ha}^{-1}$ of $\mathrm{DM}$ in comparison to the treatment that received only mineral fertilization.

Mazza et al. (2009), studying nitrogen fertilization in the productivity and chemical composition of Mombasa grass, observed that nitrogen fertilization increased up to 30 times the dry mass production in comparison to the control (without nitrogen fertilization) in the treatment with highest dose (510 kg of $\mathrm{N} \mathrm{ha}^{-1}$ ).

According to Lopes et al. (2013), the behavior shown by the forage production confirms the importance of nitrogen for biomass increment in intensively managed forages. For the PDL dose of $20 \mathrm{Mg} \mathrm{ha}^{-1}$ associated with mineral fertilization, $321 \mathrm{~kg} \mathrm{ha}^{-1}$ of $\mathrm{N}$ were applied, of which $161 \mathrm{~kg} \mathrm{ha}^{-1}$ were through PDL and $160 \mathrm{~kg} \mathrm{ha}^{-1}$ at planting and as topdressing using urea as source.

Therefore, the obtained results (Figure 3) are consistent with Araújo et al. (2011), who highlighted that the use of manure as the only source of $\mathrm{N}$ is insufficient for the plant to express its full genetic potential, since there is no amount of $\mathrm{N}$ readily available.

However, as the fits were linear it means that the PDL doses applied were not sufficient for the forage to reach its maximum production potential in the four cuttings evaluated.

The highest crude protein (CP) contents were obtained using PDL doses of 15 and $20 \mathrm{Mg} \mathrm{ha}^{-1}$ plus mineral fertilization, and the CP contents were above $9 \%$ (Table 2). For each dose, with MF, CP was statistically higher, due to the higher doses of $\mathrm{N}$, since the higher the dose of PDL, the larger the amount of $\mathrm{N}$ available. According to Freitas et al. (2007), this probably occurred because of the greater presence of free amino acids, which maintain $\mathrm{N}$ in their structure, and small peptides in plant tissue in response to the higher $\mathrm{N}$ supply in the soil.

Marques et al. (2016), studying times of $\mathrm{N}$ application in Massai grass in greenhouse, found a linear increase in the average crude protein content with the increase in $\mathrm{N}$ doses.

Similar results were found by Barnabé et al. (2007), who evaluated Brachiaria brizantha cv. Marandu fertilized with liquid swine manure and observed higher contents, using 
Table 2. Crude protein (CP, \%) of Panicum maximum cv. Mombasa, as a function of mineral fertilization (MF) for different dose of pig deep-litter (PDL)

\begin{tabular}{|c|c|c|c|c|c|c|c|c|}
\hline \multirow{2}{*}{$\begin{array}{c}\text { PDL } \\
\left(\mathrm{Mg} \mathrm{ha}^{-1}\right)\end{array}$} & \multicolumn{2}{|c|}{$1^{\text {st }}$ cutting } & \multicolumn{2}{|c|}{$2^{\text {nd }}$ cutting } & \multicolumn{2}{|c|}{$3^{\text {rd }}$ cutting } & \multicolumn{2}{|c|}{$4^{\text {th }}$ cutting } \\
\hline & Without MF & With MF & Without MF & With MF & Without MF & With MF & Without MF & With MF \\
\hline & \multicolumn{8}{|c|}{$\mathrm{CP}(\%)$} \\
\hline 0 & $6.07 \mathrm{~b}$ & $7.54 \mathrm{a}$ & $6.08 b$ & $7.51 \mathrm{a}$ & $5.86 \mathrm{~b}$ & $7.81 \mathrm{a}$ & $6.02 \mathrm{~b}$ & $7.80 \mathrm{a}$ \\
\hline 5 & $6.34 \mathrm{~b}$ & $8.50 \mathrm{a}$ & $6.34 b$ & $8.53 \mathrm{a}$ & $6.21 b$ & $8.06 \mathrm{a}$ & $6.70 b$ & $7.96 \mathrm{a}$ \\
\hline 10 & $7.06 \mathrm{~b}$ & $9.19 \mathrm{a}$ & $7.06 \mathrm{~b}$ & $9.19 \mathrm{a}$ & $7.30 \mathrm{~b}$ & $8.23 \mathrm{a}$ & $7.35 b$ & $9.05 \mathrm{a}$ \\
\hline 15 & $8.82 \mathrm{~b}$ & $9.97 \mathrm{a}$ & $8.98 \mathrm{~b}$ & $9.96 \mathrm{a}$ & $7.85 b$ & $8.63 \mathrm{a}$ & $7.81 \mathrm{~b}$ & $9.32 \mathrm{a}$ \\
\hline 20 & $8.88 \mathrm{~b}$ & $10.21 \mathrm{a}$ & $9.19 b$ & $10.24 \mathrm{a}$ & $8.08 b$ & $9.08 \mathrm{a}$ & $8.44 \mathrm{~b}$ & $9.64 \mathrm{a}$ \\
\hline CV (\%) & \multicolumn{2}{|c|}{2.06} & \multicolumn{2}{|c|}{1.32} & \multicolumn{2}{|c|}{1.03} & \multicolumn{2}{|c|}{1.99} \\
\hline
\end{tabular}

Means followed by the same letter in the row for each cutting do not differ at $\mathrm{p} \leq 0.05$ by Scott-Knott test; CV - Coefficient of variation

the doses of 100 and $150 \mathrm{~m}^{3} \mathrm{ha}^{-1}$ of manure and chemical fertilization.

According to Soest (1994), when the CP contents of forage crops are less than $7 \%$, there is a reduction in their digestion due to inadequate $\mathrm{N}$ contents for rumen microorganisms, decreasing their population and, consequently, reducing digestibility and dry mass intake. Thus, higher CP content is necessary to meet the protein requirements of the animal organism. Based on the statement, it can be seen that Mombasa grass would satisfactorily meet the minimum requirements of ruminants with PDL doses plus mineral fertilization.

Regarding the regression evaluation for the interaction between mineral fertilization and pig deep-litter, there was a linear behavior, showing that with increase in PDL doses, there is also an increment in crude protein contents (Figures $4 \mathrm{~A}$ and $\mathrm{B})$.

Simonetti et al. (2016), analyzing the productivity of Mombasa grass under different doses of biofertilizers, found that the highest doses of biofertilizer $\left(200 \mathrm{~m}^{3} \mathrm{ha}^{-1}\right)$ led to differences between the other treatments, evidencing its influence on forage quality for protein content.

According to Barnabé et al. (2007), nitrogen fertilization through the supply of $\mathrm{N}$ readily available to plants has shown significant influence on several quantitative and qualitative variables inherent to pasture management. Generally, nitrogen

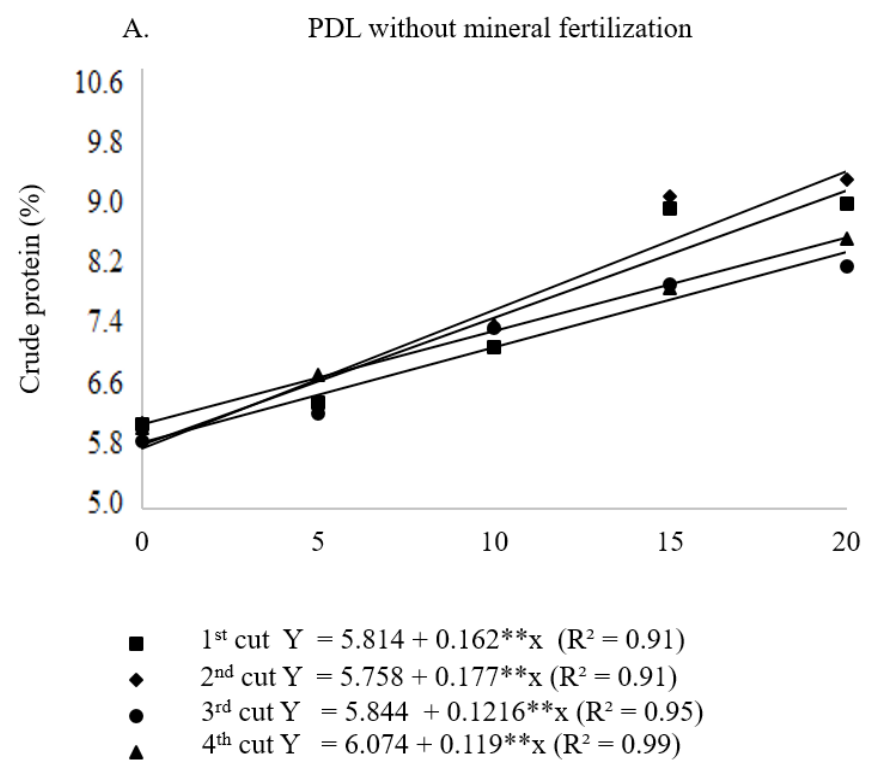

is absorbed by the plant and joins the carbon chains to form the amino acids, increasing the $\mathrm{CP}$ content of the forages.

The NDF contents in the first cutting ranged from 69.9 to $74.26 \%$, and in the associated fertilization with PDL plus mineral fertilization, NDF values were always higher than those found under PDL without mineral fertilization (Table 3).

In the second cutting, the NDF contents ranged from 66.01 to $75.97 \%$ and were higher without MF at the PDL doses from 0 to $10 \mathrm{Mg} \mathrm{ha}^{-1}$ (Table 3 ). In the third cutting, the values varied from 64.75 to $73.75 \%$, and PDL led to lower values of NDF compared to PDL + MF. In the fourth cutting, the values were between 71.85 and $76.33 \%$, and at all doses there were lower values for NDF without mineral fertilization.

NDF indicates the total amount of fiber within the bulkage, which relates it to consumption. Thus, the lower the content of NDF, the higher the dry mass intake. NDF contents vary according to plant species and vegetative stage. NDF measures all the fiber or volume component (bulkage) - hemicellulose, cellulose and lignin, being useful to estimate voluntary consumption (Rodrigues, 2010).

Food NDF content represents the fraction of non-soluble fiber in neutral detergent and can be used by technicians and producers of ruminant animals for balancing diets with adequate dietary fiber contents (Simonetti et al., 2016). In general, both the quality and quantity of dietary fiber present

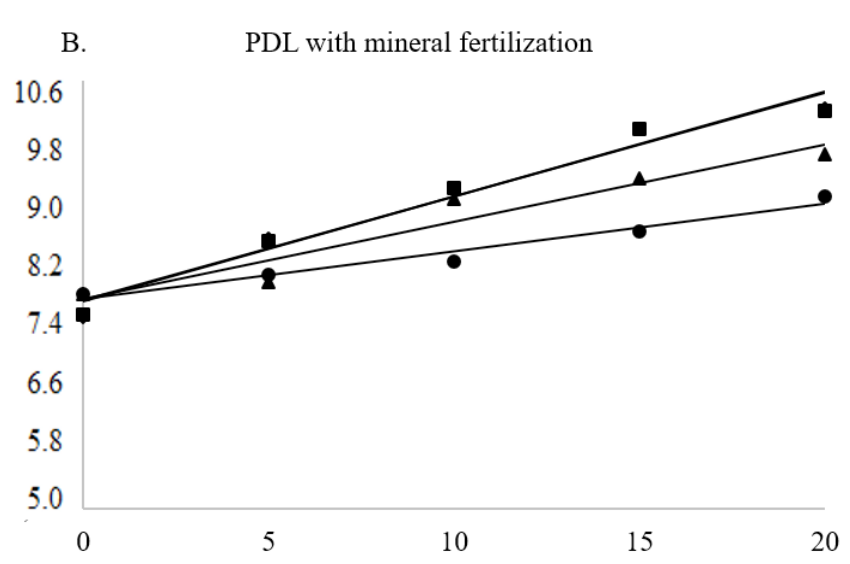

"* Significant at $\mathrm{p} \leq 0.01$ by $\mathrm{F}$ test

Figure 4. Crude protein (CP) contents of Mombasa grass as a function of pig deep-litter doses without (A) and with (B) mineral fertilization (MF), referring to the averages of the four cuts 
Table 3. Contents of neutral detergent fiber (NDF \%) and acid detergent fiber (ADF \%) of Panicum maximum cv. Mombasa, as a function of fertilization with pig deep-litter, with or without mineral fertilization (MF)

\begin{tabular}{|c|c|c|c|c|c|c|c|c|}
\hline \multirow{2}{*}{$\begin{array}{c}\text { PDL } \\
\left(\mathrm{Mg} \mathrm{ha}^{-1}\right)\end{array}$} & \multicolumn{2}{|c|}{$1^{\text {st }}$ cutting } & \multicolumn{2}{|c|}{$2^{\text {nd }}$ cutting } & \multicolumn{2}{|c|}{$3^{\text {rd }}$ cutting } & \multicolumn{2}{|c|}{$4^{\text {th }}$ cutting } \\
\hline & Without MF & With MF & Without MF & With MF & Without MF & With MF & Without MF & With MF \\
\hline & \multicolumn{8}{|c|}{ NDF (\%) } \\
\hline 0 & $72.60 \mathrm{~b}$ & $74.26 a$ & $75.97 a$ & $72.22 \mathrm{~b}$ & $67.28 \mathrm{~b}$ & $73.75 a$ & $74.77 \mathrm{~b}$ & $76.33 a$ \\
\hline 5 & $72.12 b$ & $73.06 a$ & $74.62 \mathrm{a}$ & $71.26 \mathrm{~b}$ & $66.26 \mathrm{~b}$ & $72.90 \mathrm{a}$ & $73.96 \mathrm{~b}$ & $76.03 a$ \\
\hline 10 & $71.32 \mathrm{~b}$ & $72.69 a$ & $73.49 \mathrm{a}$ & $70.85 b$ & $65.97 \mathrm{~b}$ & $71.41 \mathrm{a}$ & $73.06 \mathrm{~b}$ & $75.80 \mathrm{a}$ \\
\hline 15 & $70.83 \mathrm{~b}$ & $71.75 a$ & $67.97 a$ & $68.11 a$ & $64.95 b$ & $70.19 a$ & $72.71 b$ & $74.34 a$ \\
\hline 20 & $69.90 \mathrm{~b}$ & $70.55 a$ & $66.60 \mathrm{a}$ & $66.01 \mathrm{a}$ & $64.75 b$ & $68.83 a$ & $71.85 b$ & $73.95 \mathrm{a}$ \\
\hline \multirow[t]{2}{*}{ CV (\%) } & \multicolumn{2}{|c|}{0.88} & \multicolumn{2}{|c|}{0.95} & \multicolumn{2}{|c|}{0.84} & \multicolumn{2}{|c|}{0.85} \\
\hline & \multicolumn{8}{|c|}{ ADF (\%) } \\
\hline 0 & $43.52 a$ & $41.12 b$ & $44.08 \mathrm{a}$ & $40.09 b$ & $39.67 a$ & $35.97 \mathrm{~b}$ & $53.22 \mathrm{a}$ & $43.77 b$ \\
\hline 5 & $42.48 \mathrm{a}$ & $40.76 \mathrm{~b}$ & $43.22 \mathrm{a}$ & $41.15 b$ & $38.16 \mathrm{a}$ & $35.91 b$ & $52.79 a$ & $42.70 \mathrm{~b}$ \\
\hline 10 & $41.87 a$ & $39.80 \mathrm{~b}$ & $42.75 \mathrm{a}$ & $42.45 a$ & $36.76 a$ & $34.83 b$ & $51.06 a$ & $41.95 b$ \\
\hline 15 & $41.25 a$ & $39.08 b$ & $41.86 b$ & $43.95 a$ & $35.83 a$ & $32.85 b$ & $49.31 \mathrm{a}$ & $41.75 b$ \\
\hline 20 & $40.47 a$ & $38.47 \mathrm{~b}$ & $40.27 b$ & $44.94 a$ & $33.72 a$ & $31.11 \mathrm{~b}$ & $49.10 \mathrm{a}$ & $39.92 b$ \\
\hline CV $(\%)$ & \multicolumn{2}{|c|}{1.55} & \multicolumn{2}{|c|}{1.21} & \multicolumn{2}{|c|}{1.92} & \multicolumn{2}{|c|}{1.28} \\
\hline
\end{tabular}

Means followed by the same letter in the row for each cutting do not differ at $\mathrm{p} \leq 0.05$ by Scott-Knott test; CV - Coefficient of variation

in forage plants are key variables that can influence the DM intake by animals.

In studies with different grazing heights, Rego et al. (2003) found NDF values from 58 to $72 \%$ for leaves and from 77 to $83 \%$ for stems. Euclides (1995), studying several cultivars of Panicum maximum, concluded that NDF contents lower than $55 \%$ are rare, higher than $65 \%$ are common in new tissues and contents between 75 and $80 \%$ are found in materials of advanced maturity. These results are in line with the observed in this study, in which the fourth cutting showed higher values of NDF, since the material was in an advanced state of maturity and with scarcity of rain.

The average levels of acid detergent fiber (ADF) ranged from 43.52 to $38.47 \%$, and at all doses lower values were found without mineral fertilization. (Table 3 ). In second cutting, the contents ranged from 40.27 to $44.94 \%$. Without mineral fertilization, the ADF contents were higher at the PDL doses 0 and $5 \mathrm{Mg} \mathrm{ha}^{-1}$ and lower at the PDL doses of 15 and $20 \mathrm{Mg} \mathrm{ha}^{-1}$. In third cutting, the values ranged from 31.11 to $39.67 \%$, and at all doses the ADF contents were lower without mineral fertilization. In the fourth cutting, the values ranged from 53.22 to $39.92 \%$, and continued with lower values at all doses of PDL without MF (Table 3). These results are higher than those reported by Medeiros et al. (2007), who found mean values of $28.80 \%$ when evaluating Brachiaria brizantha cv. Marandu fertigated with liquid swine manure.

ADF indicates digestibility, that is, the amount of fiber that is not digestible since it contains the highest proportion of lignin, an indigestible fraction of fiber. ADF is an indicator of energy value: the lower the $\mathrm{ADF}$, the higher the energy value. ADF measures the most indigestible components, cellulose and lignin (Rodrigues, 2010).

Freitas et al. (2007) found the lowest contents of NDF (66.09\%) and $\operatorname{ADF}(32.15 \%)$ in the grass subjected to fertilization with $150 \mathrm{~m}^{3} \mathrm{ha}^{-1}$ year ${ }^{-1}$ of liquid swine manures, hence suggesting that the highest doses of biofertilizers can improve the bromatological conditions of the grass.

\section{Conclusion}

Applications of pig deep-litter up to the dose of $20 \mathrm{Mg} \mathrm{ha}^{-1}$ associated with mineral fertilization promoted higher dry mass productivity, increasing the contents of crude protein (CP) and decreasing the contents of neutral detergent fiber (NDF) and acid detergent fiber (ADF).

\section{Literature Cited}

Araújo, A. dos S.; Silva, J. E. C. da; Santos, A. C. dos; Silva Neto, S. P. da; Dim, V. P.; Alexandrino, E. Substituição de nitrogênio por esterco bovino na produtividade de forragem e qualidade do solo. Revista Brasileira de Saúde e Produção Animal, v.12, p.852-866, 2011.

Araújo, L. C. de; Santos, A. C. dos; Ferreira, E. M.; Cunha, O. F. R. Fontes de matéria orgânica como alternativa na melhoria das características químicas do solo e produtividade do capimmombaça. Revista de Ciências Agrárias e Ambientais, v.6, p.65-72, 2008. https://doi.org/10.7213/cienciaanimal.v6i1.10358

Barcellos, A. O.; Ramos, A. K. B.; Vilela, L.; Junior, G. B. M. Sustentabilidade da produção animal baseada em pastagens consorciadas e no emprego de leguminosas exclusivas, na forma de banco de proteína, nos trópicos brasileiros. Revista Brasileira de Zootecnia, v.37, p.51-67, 2008. https://doi.org/10.1590/S151635982008001300008

Barnabé, M. C.; Rosa, B.; Lopes, E. L.; Rocha, G. P.; Freitas, K. R.; Pinheiro, E. de P. Produção e composição bromatológica da Brachiaria brizantha cv. Marandu adubada com dejetos líquidos de suínos. Ciência Animal Brasileira, v.8, p.435-446, 2007.

Cantarutti, R. B.; Alvares V., V. H.; Ribeiro, A. C. Pastagens. In: Ribeiro, A. C.; Guimaraes, P. T. G.; Alvarez V., V. H. (eds.). Recomendação para o uso de corretivos e fertilizantes em Minas Gerais: Quinta aproximação. Viçosa: Comissão de Fertilidade do Solo do Estado de Minas Gerais, 1999. Cap.18, p.332-341.

Cardoso, B. F.; Oyamada, G. C.; Silva, C. M. da. Produção, tratamento e uso dos dejetos suínos no Brasil. Desenvolvimento em Questão, v.13, p.127-145, 2015. https://doi.org/10.21527/22376453.2015.32.127-145

Carvalho, W. T. V.; Minighin, D. C.; Gonçalves, L. C.; Villanova, D. F. Q.; Mauricio, R. M.; Pereira, R. G. V. Pastagens degradadas e técnicas de recuperação: Revisão. Pubvet, v.11, p.1036-1045, 2017. https://doi.org/10.22256/pubvet.v11n10.1036-1045

Euclides, V. P. B. Valor alimentício das espécies forrageiras do gênero Panicum. In: Simpósio sobre Manejo da Pastagem, 12, 1995, Piracicaba. Anais... Piracicaba: FEALQ, 1995. p.245-274. 
Ferreira, D. F. Sisvar: A computer statistical analysis system. Ciência e Agrotecnologia, v.35, p.1039-1042, 2011. https://doi.org/10.1590/ S1413-70542011000600001

Freitas, K. R.; Rosa, B.; Ruggiero, J. A.; Nascimento, J. L. do; Heinemam, A. B.; Macedo, R. F.; Naves, M. A. T.; Oliveira, I. P. de. Avaliação da composição químico-bromatologica do capim mombaca (Panicum maximum) submetidos a diferentes doses de nitrogênio. Bioscience Journal, v.23, p.1-10, 2007.

Hentz, P; Scheffer-Basso, S. M.; Escosteguy, P. A. V.; Fontaneli, R. S. Utilização de cama sobreposta de suínos e sobressemeadura de leguminosas para aumento da produção e qualidade de pastagem natural. Revista Brasileira de Zootecnia, v.37, p.1537-1545, 2008. https://doi.org/10.1590/S1516-35982008000900004

Homem, B. G. C.; Arcanjo, A. G. M.; Oliveira, P. C. S.; Almeida Neto, O. B. de; Trindade, A. G.; Nogueira, M. A. dos R.; Cidrini, I. A. Avaliação do potencial agronômico de dois tipos de cama sobreposta de suínos. Vértices, v.17, p.65-75, 2015. https://doi. org/10.19180/1809-2667.v17n315-03

INMET - Instituto Nacional de Meteorologia. Consulta Dados da Estação Convencional: Ipameri (GO). Available at: <http://www. inmet.gov.br/sim/sonabra/dspDadosCodigo.php?ODM1MjI=> Accessed in: May 2016.

Lopes, M. N.; Cândido, M. J. D.; Pompeu, R. C. F.; Silva, R. G.; Lopes, J. W. B.; Fernandes, F. R. B.; Lacerda, C. F.; Bezerra, F. M. L. Fluxo de biomassa em capim-massai durante o estabelecimento e rebrotação com e sem adubação nitrogenada. Revista Ceres, v.60, p.363-371, 2013. https://doi.org/10.1590/S0034-737X2013000300009

Marques, A. C. R.; Rigodanzo, E. L.; Basso, L. J.; Krolow, R. H.; Missio, M. Dejeto de leiteria como alternativa para a adubação do consórcio aveia preta e azevém e seus efeitos na produção e qualidade bromatológica da forragem. Revista Brasileira de Agroecologia, v.11, p.188-195, 2016.

Martha Júnior, G.B.; Vilela, L. Pastagens no Cerrado: Baixa produtividade pelo uso limitado de fertilizantes. Planaltina: Embrapa Cerrados, 2002.32p. Documentos, 50.
Mazza, L. de M.; Pôggere, G. C.; Ferraro, F. P.; Ribeiro, C. B.; Cherobim, V. F.; Motta, A. C.; Moraes, A. Adubação nitrogenada na produtividade e composição química do capim mombaça no primeiro planalto paranaense. Scientia Agraria, v.10, p.257-265, 2009. https://doi.org/10.5380/rsa.v10i4.14915

Medeiros, L. T.; Rezende, A. V. de; Vieira, P. de F.; Cunha Neto, F. R. da; Valeriano, A. R.; Casali, A. O. Gastaldello Junior, A. L. Produção e qualidade da forragem de capim-Marandu fertiirrigada com dejetos líquidos de suínos. Revista Brasileira Zootecnia, v.36, p.309-318, 2007. https://doi.org/10.1590/S1516-35982007000200006

Orrico Junior, M. A. P.; Centurion, S. R.; Orrico, A. C. A.; Sunada, N. da S. Effects of biofertilizer rates on the structural, morphogenetic and productive characteristics of Piatã grass. Revista Brasileira de Zootecnia, v.41, p.1378-1384, 2012. https://doi.org/10.1590/ S1516-35982012000600009

Rego, F. C. A.; Cecato, U.; Damasceno, J. C.; Ribas, N. P.; Santos, G. T. dos; Moreira, F. B.; Rodrigues, A. M. Valor nutritivo do capimTanzania (Panicum maximum Jacq cv. Tanzania-1) manejado em alturas de pastejo. Acta Scientiarum. Animal Sciences, v.25, p.363-370, 2003. https://doi.org/10.4025/actascianimsci.v25i2.205

Rizzoni, L. B.; Tobias, A. C. T.; Bianchi, M. del; Garcia, J. A. D. Biodigestão anaeróbia no tratamento de dejetos de suínos. Revista Científica Eletrônica de Medicina Veterinária, v.9, p.1-20, 2012.

Rodrigues, R. C. Métodos de análises bromatológicas de alimentos: Métodos físicos, químicos e bromatológicos. Pelotas: Embrapa Clima Temperado, 2010. 177p. Documentos, 306.

Silva, D. J.; Queiroz, A. C. de. Análise de alimentos: Métodos químicos e biológicos. 3.ed. Viçosa: Editora UFV, 2006. 235p.

Simonetti, A.; Marques, W. M.; Costa, L. V. C. Produtividade de capim-mombaça (Panicum maximum), com diferentes doses de biofertilizantes. Brazilian Journal of Biosystems Engineering, v.10, p.107-115, 2016. https://doi.org/10.18011/ bioeng2016v10n1p107-115

Soest, P. J. van. Nutritional ecology of the ruminant. 2.ed. New York: Cornell University, 1994. 476p. 